\title{
How Could Aristotle Defend The Self-sufficiency Of Political Life While Claiming The Superiority Of Contemplative Life?
}

\section{Serdar Tekin}

\begin{abstract}
In Nicomachean Ethics X.7, Aristotle argues that perfect happiness consists in contemplation alone. The question that I want to take up in this essay is whether the superiority of contemplative life fits with Aristotle's argument for the self-sufficiency of the political life, according to which politics can lead us to happiness without being guided by philosophical knowledge of the highest sort. My basic argument is that, paradoxical as it may seem, Aristotle is led to acknowledge that contemplative life is superior to political life by the same strand of argumentation which makes him plea for the self-sufficiency of the political life in the first place. In order to show how this argument unfolds, I take my point of departure from Aristotle's analysis of phronēsis as stated in Nicomachean Ethics VI and bring it to bear on his discussion of the respective virtues of the contemplative and political ways of life in Politics VII.
\end{abstract}

Keywords: Aristotle, phronēsis, practical reason, contemplative life, political life

Özet: Aristoteles Nikomakhos'a Etik X.7'de en yüksek mutluluğun teorik yaşamda bulunduğu görüşünü dile getirir. Bu yazı, söz konusu görüşün, politik yaşamın kendine yeterli olduğu-yani en yüksek türdeki felsefi bilginin kılavuzluğuna ihtiyaç duymaksızın insansal mutluluğu temin edebileceği-şeklindeki bir diğer Aristotelesçi görüşle uyumlu olup olmadığı sorununu ele alıyor. Yazının temel savı şu şekilde ifade edilebilir: Aristoteles, her ne kadar paradoksal gibi görünse de, teorik yaşamın üstünlüğünü ve politik yaşamın kendine yeterliliğini aynı felsefi zeminden hareketle savunmaktadır. Söz konusu felsefi zemini serimlemek üzere, yazıda ilk olarak Nikomakhos'a Etik VI'daki phronessis analizi, ardından da Politika VII'deki teorik ve politik yaşam karşılaştırması inceleniyor.

Anahtar Sözcükler: Aristoteles, phronēsis, pratik akıl, teorik yaşam, politik yaşam

\section{Introduction}

In Nicomachean Ethics X.7, Aristotle famously argues that perfect happiness consists in contemplation alone.1 Much ink has been spilled on this claim if for no other reason than that its relation to the overarching argument of Nicomachean Ethics is apparently unclear. In the bulk of the text, Aristotle

Tekin, Serdar. (2016). How Could Aristotle Defend The Self-sufficiency Of Political Life While Claiming The Superiority Of Contemplative Life? Kilikya Felsefe Dergisi 3. pp. 13-26.

1 For Nicomachean Ethics (hereafter NE), I use the Ross edition; for Politics (hereafter Pol.), I use the Lord edition. Full references are available in the bibliography. 
the full range of acting well-including friendship, practical wisdom and the virtues of the character-as essential constituents of human happiness. According to some, therefore, Aristotle's emphasis on contemplation as the sole human activity with pure intrinsic value and hence the only true path to happiness stands in tension with the rest of his moral philosophy (Cooper, 1975, pp. 155-180; Nussbaum, 1986, pp. 375-376). By contrast, others hold that there is no such contradiction or inconsistency, and that the superiority of contemplation is compatible with what Aristotle has said earlier in the text (Rorty, 1980; Kraut, 1989, pp. 3-77). Still others, avoiding both of these somewhat strong positions, seem to think that there is an indecision in Aristotle and that he wavers between two accounts of eudaimonia, an "intellectualist" and a "comprehensive" one (Nagel, 1972; Ackrill, 1974; Moline, 1983). Obviously, the debate is not simply about textual consistency or inconsistency, but bears on Aristotle's practical philosophy as a whole. After all, if happiness is the ultimate human good, as Aristotle so emphatically wants to have us believe, then, what it consists in (and by extension, what sort of life would make us happy) turns out to be the most important practical question of all.

In what follows, I take up this interpretive problem from a specific angle: namely, from the standpoint of its implications for Aristotle's political philosophy. Arguably, what distinguishes Aristotle's Politics from Plato's Republic at a fundamental conceptual level is the insight that the highest form of knowledge that human beings can reach in the theoretical realm has little to say about the right thing to do in the domain of human action. This insight is accompanied by (and cannot be isolated from) Aristotle's emphasis on the "self-sufficiency" (autarkeia) of the city (Pol. 1252b29). As I take it, self-sufficiency in the Aristotelian sense implies, in contrast to the main thrust of Plato's Republic, that political life can lead us to happiness without being guided by philosophical knowledge of the highest sort. Accordingly, the question that I want to address is whether or to what extent this vision of a self-sufficient political life fits with the superiority of contemplation as stated in Nicomachean Ethics X.7.

My basic argument is that, paradoxical as it may seem, Aristotle is led to acknowledge the superiority of the contemplative life by the same vein of argumentation which makes him plea for the self-sufficiency of the political life. In order to show how this argument unfolds, I start with 
Aristotle's account of phronèsis ${ }^{2}$ as it appears in Nicomachean Ethics VI. Then, turning to Aristotle's treatment of the political and the contemplative ways of life in Politics VII, I will map out the ways in which the self-sufficiency of the political life is grounded in phronessis. Finally, I will visit Nicomachean Ethics X.7 so as to see whether or not the superiority of the contemplative life would fit with the idea of a self-sufficient political life.

\section{I.}

In The Idea of the Good in Platonic-Aristotelian Philosophy, Hans-Georg Gadamer argues that there is a "unitary effect connecting Plato's and Aristotle's logos philosophy" (1986, p. 1). What they share in common, according to Gadamer, is premised on the Socratic insight that "we understand the world starting with the experience of the good" (1986, p. 128). However, Gadamer also notes that we find in Aristotle nothing less than a radical reconstruction of the Socratic-Platonic heritage. Aristotle approaches "the experience of the good" not so much from the vantagepoint of its general idea but from the perspective of the ways in which it is practically shared in the realm of human action. In Gadamer's words:

In an explicit polemic, Aristotle distinguished the human good, after which he inquired, from the universal idea of the good, about which Socrates asked in so many ways in the Platonic corpus. If Plato unifies the good of the soul, the good of the polis, and the good of the universe, this magnificent Pythagorean vision of the world is established on a numerical-theoretical basis. This could not promise any proper satisfaction in the search for happiness to the human life struggling in its tasks and for its goals. The famous anecdote about the Platonic lecture "On the Good" and its reception by the Attic public testifies to this fact. In his polemic counter-construction, Aristotle does not build practical philosophy on the general idea of the good; rather, his point of departure (principle, archē, the first beginning) is "the that" (to hoti). (1999, p. 57)

The last point concerning "the that" directly refers to Aristotle's Nicomachean Ethics, where he maintains that "the fact [to hoti] is the

2 In what follows, I use the original Greek word phronēsis instead of its equivalents in English, "practical wisdom" or "prudence." In his edition of Nicomachean Ethics, Ross prefers the former whereas Lord prefers the latter in his edition of The Politics. For the sake of terminological consistency, I keep the Greek original in the quotations as well. 
starting-point" of all moral and political discourse (NE 1095b6).

The appeal to "the that" has two far-reaching implications for Aristotle's practical philosophy. First, it allows him to work through the "prominent types of life" as they are understood and embodied in the Greek society: these are the life of enjoyment, the political life, and the contemplative life (NE 1095b15-20). Regardless of their respective values, each of them designates a fundamental feature of human existence: namely, "desire," "action," and "wonder," respectively. To proceed from "the that" is to proceed from "the self-projection of human existence" (Gadamer, 1999, p. 58). Secondly, taking his point of departure from "the that," Aristotle inquires into the peculiar mode of thinking embedded in the realm of human practice, a way of thinking that proceeds in an essentially different fashion from philosophical reasoning. The excellence of this practical thinking is what Aristotle calls phronēsis.

Aristotle's treatment of phronessis starts with an overall assessment of his theory of moral virtues, i.e., the virtues of character. The conceptual nerve of this theory, which covers almost the first five books of Nicomachean Ethics, is the idea that the good lies in the mean which is to be determined "by the dictates of the right rule" (NE 1138b20). Yet, at the beginning of book VI, Aristotle acknowledges that such a statement does not make much sense without being supplemented by an illustration of what the right reason or the right principle (orthos logos) is and how it is to be grasped. This point recalls the famous metaphor of the "archer hitting the mark" with which Aristotle has begun his lectures on ethics. It involves the fundamental question that will lead us to the heart of practical philosophy: how does one "hit upon what is right" (NE 1094a25)?

To address the question, Aristotle undertakes a penetrating study of intellectual virtues. There are two parts in the human soul, he tells us, which are capable of grasping a rational principle: "one by which we contemplate the kind of things whose originative causes are invariable, and one by which we contemplate variable things; for where objects differ in kind the part of the soul answering to each of the two is different in kind, since it is in virtue of a certain likeness and kinship with their objects that they have the knowledge they have" (NE 1139a5-15). In this crucial passage, we see Aristotle distinguishing between two spheres of being as well as two modes of thinking that correspond to them. This dual distinction is of utmost significance with regards to the respective 
ontological and epistemological grounds of the contemplative and the political life. The contemplative part of the soul, which Aristotle also calls the "scientific" (to epistemmonikon), is oriented towards the realm of things which always and necessarily are. The contemplation of these eternal and imperishable things constitutes the essence of the philosophic life of the spectator. The deliberative part of the soul, which he also calls the "calculative" (to logistikon), is situated in an essentially different realm of being, i.e., in the domain of human practice where things are contingent and subject to change. They are in need of deliberation precisely because they admit of being otherwise than they are. Unlike the contemplative life of the spectator, the political life of the actor revolves around this latter faculty.

Aristotle argues that both of these faculties aim at reaching the truth with respect to their own objects. To be sure, this is just another way of saying that there are different kinds of truth. As to the contemplative part of the soul, truth demands the grasp of the first principles as well as the demonstrative knowledge, which is to be deduced from them. The deliberative part of the soul, on the other hand, addresses itself to an essentially different sort of truth that is relevant to human practice. Here, truth is defined in terms of the knowledge of what is required in a concrete (moral and/or political) situation. Put differently, the knowledge of the right thing to do comes to the foreground as the hallmark of truth in the practical world. The attainment of such knowledge, however, is not the end result of a pure process of reasoning, but depends on a set of conditions that eventually determine the appropriateness of deliberation. We should now look at more closely what these conditions are.

\section{II.}

After having clarified the rational faculties of the soul, Aristotle moves on to the question of their respective virtues. He distinguishes five modes of possessing truth so as to elicit the excellence in knowing truly.

Let it be assumed that the states by virtue of which the soul possesses truth by way of affirmation or denial are five in number, i.e., art [technē], scientific knowledge [epistēmē], practical wisdom [phronēsis], philosophic wisdom [sophia], intuitive reason [nous]; we do not include judgement and opinion because in these we may be mistaken. (NE 1139b15-20) 
It is significant to note that these five concepts do not designate the capacities or the faculties of the soul. Rather, they are the "modes" or "states" of the soul in which, thanks to its contemplative and deliberative capacities, the soul has the true knowledge of certain things. Of these Aristotle privileges sophia and phronessis as the virtues of contemplative and deliberative reason respectively. Epistēmē and nous constitute the essential components of sophia because the former gives the demonstrative knowledge which depends on and proceeds from the knowledge of starting-points, while the latter grasps these ultimate starting-points themselves, i.e., the first principles of being as they are. The fusion of both, hence, constitutes sophia as the virtue of the contemplative part of the soul. Aristotle describes technē as the state of mind characterized by the perfect knowledge of making or fabrication. On the one hand, it is essentially different from contemplative modes of knowing because its objects belong to the world of variable things; yet, on the other hand, it bears no similarity to phronēsis for making/fabrication (poiēsis) and action (praxis) are essentially different as Aristotle is very sensitive to emphasize: "the reasoned state of capacity to act is different from the reasoned state of capacity to make" since "neither is acting making nor is making acting" (NE 1140a5-10). The meticulous analysis of these concepts finally helps Aristotle distinguish phronesis as the "true and reasoned state of capacity to act with regard to the things that are good or bad for man" (NE 1140b5).

Three points seem to me crucial in this definition. First of all, phronēsis is about what is "good or bad for man" in an unqualified sense; that is to say, "not in some particular respect, e.g. about what sorts of things conduce to health or to strength, but about what sorts of things conduce to the good life in general" (NE 1140a25-30). Thus, it involves a true cognition of what it means to be a human being and to live accordingly. Secondly, although it refers to the human good in general, phronesis inevitably addresses itself to the particulars in its way of proceeding. It is not a conceptual comprehension of what goodness is in and of itself (like, say, the Platonic form of the good), but the perception of the things that are good for man. In other words, the work of phronesis is to discern what is to be done within the infinite diversity of particular situations and circumstances. After all, it is nothing but this irreducible particularity and inexhaustible variety of concrete situations among which human practice should find its way that theoretical reason is unable to predict and cope with. In this regard, an essential feature of phronessis is the ability to sit in judgment on particular situations. 
Last but not least, phronēsis is not only a true cognition of human good and an ability to judge well, but also a "reasoned state of capacity to act." The emphasis on action stems from the fact that the question of what to do or how to act is implicit in deliberation. As Aristotle puts it, no one deliberates about "things that it is impossible for him to do" (NE 1140a3035). However, it is well possible that one may lack the desire or the power to act in a certain way although that way of action is not impossible to follow. Hence, there is a further and deeper connection between phronessis and action. This connection comes to the foreground in the following passage, where Aristotle distinguishes phronēsis from sunesis, i.e., from understanding in the sense of being able to perceive the meaning of a given situation: "Hence it [sunesis] is about the same objects as phronēsis; but understanding [sunesis] and phronessis are not the same. For phronessis issues commands since its end is what ought to be done or not to be done; but understanding only judges." (NE 1143a5-10) Here phronēsis is described in terms of its capacity to "issue commands" and to generate action. But what does it actually mean?

To illuminate this point, we must briefly visit Aristotle's discussion of the relation between action, deliberation, and desire. Aristotle tells us that the efficient cause of all action is "intentional choice" (proairesis) which, in turn, depends on "desire and reasoning with a view to an end" (NE 1139a30-35). Accordingly, he describes intentional choice as either "desiderative reason" or "ratiocinative desire" (NE 1139b1-5). For the action to be good, thus, both the deliberation must be true and the desire must be in accordance with it. Read in this light, what distinguishes phronessis from sunesis, namely what makes phronessis capable of issuing commands (in a way that sunesis is not capable) is its capacity to have an impact on desire and to bring it in line with true deliberation. Therefore, as Ronald Beiner (1983, p. 74) aptly notes, "the lack of phronessis is not just a failure of judgment" for Aristotle, but at the same time "really a failure of action" or, one might say, a failure of good action.

To sum up, then, in light of the foregoing we can underline three essential features of phronessis: (1) it involves a general grasp of what constitutes the human good and what is to lead a good life; furthermore (2) this grasp reveals itself not as a philosophical comprehension, but as the knowledge of the right thing to do with respect to a particular situation; and finally (3) its modus operandi is effective not only on the purposes of good action, but also on its originative causes including desire. Let me 
turn now to the question of how Aristotle's account of phronessis informs his treatment of the political and the contemplative life.

III.

Aristotle opens Politics VII with two questions related to each other: "which is the most choiceworthy way of life for all" and "whether the same or a different way of life is choiceworthy [for men] in common and separately [as individuals]" (Pol. 1323a20-25). He situates these questions into the context of the debate between two competing claims over the content of the good life:

[T]here is a dispute among those who agree that the most choiceworthy way of life is that accompanied by virtue as to whether the political and active way of life is choiceworthy, or rather that which is divorced from all external things-that involving some sort of study, for example-which some assert is the only philosophic way of life. For it is evident that these two ways of life are the ones intentionally chosen by those human beings who are most ambitious with a view to virtue, both in former times and at the present; the two I mean are the political and the philosophic. (Pol. 1324a25-35)

Notice that Aristotle presents both the political and the contemplative life as embodiments of the "intentional choice" towards virtue. This reference to intentional choice seems to have two functions. First, it serves to treat philosophy and politics on a common ground, namely from the standpoint of the human search for happiness. And secondly, it admits of considering the ways in which people actually understand and engage in these life projects. While the former provides the basic framework for Aristotle's discussion, the latter constitutes its starting-point.

Let us ask, then, how the men of action, on the one hand, and those who adhere philosophy, on the other, conceive the respective ways of life they praise. Roughly said, the former group identifies virtue and happiness with acting well and participating in noble deeds. Their understanding of action is particularly structured in terms of courage, honor, and public reputation, all of which inevitably require the exercise of power in order to achieve greatness and distinction. Accordingly, what they praise is in fact a way of action oriented towards war and conquest with a view to ruling over other cities. Therefore, they specifically believe that "the active 
and political way of life is the only one for a man [anēr]" (Pol. 1324a40). From this point of view, the contemplative way of life seems to be far from virtue, and even unmanly and futile. The adherents of philosophy, in contrast, see a strong inclination towards tyranny in the way of life upheld by these men of action. Even when it is not accompanied by injustice and tyrannical ambition, they consider any sort of active engagement in political rule to be an impediment to one's own search for virtue and happiness, which can only be pursued through reflection. Thus, they seek retreat from the world of action and praise a private way of life dedicated to philosophical contemplation.

In the face of this controversy, Aristotle criticizes both positions as misconceiving the "active way of life" (bios praktikos) which can be pursued through philosophy as well as politics provided that these human enterprises are properly understood. Accordingly, he propounds an "activist ideal of happiness" (O'Connor, 1999), which strives to do justice to what he takes to be the best elements in both positions. This dialectical discussion can be reconstructed on the basis of the following statements: "the best is what is most choiceworthy and acting well is best" (Pol. 1325a40); yet "there is no noble deed either of a man or of a city that is separate from virtue and phronessis" (Pol. 1323b30-35). While the former point is addressed to those who privilege the contemplative way of life, the latter is addressed to those who praise political action. The adherents of the philosophical life tend to understand contemplation as divorced from all activity, and consider all forms of action to be at best futile and at worst tyrannical. In contrast, Aristotle argues that contemplation is a sort of activity and its capacity to attain happiness is essentially based thereupon. Viewed in this light, the adherents of the political life are right to the extent that they associate happiness with acting well. Nevertheless, their understanding of action, which is prone to turn politics into a matter of conquering other cities and exercising mastery over them, betrays a crucial lack of phronessis and, therefore, does not bear so much nobility as they assume.

The latter point is of particular interest for our purposes here. For the ways in which Aristotle criticizes this aggressive view of political action serve to underline how central phronessis is to a self-sufficient political life. As opposed to the assumptions of the adherents of politics, Aristotle argues that the distinctive feature of the statesman (politikos) is not "to be able to discern how to rule and exercise mastery over those nearby" (Pol. 
1324b20-25), but to see "how a city, a family of human beings, and every other sort of partnership will share in the good life and in the happiness that is possible for them" (Pol. 1325a5-10). In this regard, those who associate action with external enterprises such as war and conquest rather than with the inner felicity of the city suffer from a lack of practical truth with respect to what conduces to the good life in general-a sort of truth characteristic of phronesis as we have just seen. Moreover, not only their understanding of the ultimate purpose of action fails to fulfill the demands of phronessis, but their approach to particular cases is equally flawed. The view of action they praise does not allow them to differentiate between "what sorts of training are to be undertaken with a view to what sorts of [neighboring peoples] or how the things suitable for each sort are to be practiced" (Pol. 1325a10-15). As such, in the face of particular situations, they consider no distinction between what is to be mastered and what is not to be mastered-a fatal failure of good deliberation that may result in great injustices rather than noble deeds.

Aristotle complements these remarks by another one which designates the crucial relation between action and moral character: "actions can no longer be noble for one who does not differ as much [from those he rules] as husband differs from wife, father from children, or master from slaves" (Pol. 1325b1-5). Put differently, ruling over free people by force does not only give rise to injustice on the part of those who are unjustly mastered, but also yields a moral distortion on the part of those who exercise that mastery. This point is directly related to the instructive effect of phronessis on desires: should it be divorced from phronesis-which informs and cultivates the desire in accordance with the right principle-action tends to be self-destructive in terms of the moral character of the actor.

By virtue of this critical discussion Aristotle eventually intends to pull the adherents of both the political and the contemplative life back to the common ground of his ideal of happiness: "if these things are argued rightly and happiness is to be regarded as [the same as] acting well, the best way of life both in common for every city and for the individual would be the active one" (Pol.1325b10-15). It is important to note that Aristotle, at least here, does not imply that either political life or the contemplative life is better than the other. On the contrary, he gives an inclusive definition of the most choiceworthy life that fits both the contemplative life understood as inherently active and the political life in which action is not detached from but accompanied by phronessis. In other words, they are considered 
to be two equal and self-sufficient life projects capable of leading their followers to the good life. This is also in line with his standard definition of happiness as "the activity of soul in accordance with virtue" (NE 1098a1520). Viewed in light of this definition, the political and the contemplative ways of life share in common two general features both of which can be described as formal conditions of happiness: (1) the condition of being an "activity" and (2) the condition of being "in accordance with virtue."

IV.

Aristotle nonetheless reaches a dramatically different conclusion in Nicomachean Ethics X.7. Consider the following passage:

If happiness is activity in accordance with virtue, it is reasonable that it should be in accordance with the highest virtue; and this will be that of the best thing in us. Whether it be reason [nous] or something else that is this element which is thought to be our natural ruler and guide and to take thought of things noble and divine, whether it be itself also divine or only the most divine element in us, the activity of this in accordance with its proper virtue will be perfect happiness. That this activity is contemplative we have already said. (NE 1177a10-20)

The outstanding question is clear enough: how does this claim fit with Aristotle's deep-rooted argument for the self-sufficiency of political life? How could Aristotle argue that political life can lead us to happiness, while at the same time claiming the superiority of the contemplative life?

Let us start from the last remark in the quoted passage. Strictly speaking, as Ross mentions in an editorial note to this passage, "that this activity is contemplative" has not been said before. However, as we have already seen, Aristotle makes a closely related point in his analysis of the intellectual virtues in Nicomachean Ethics VI, where he draws a distinction between the contemplative and the deliberative parts of the soul on the basis of their respective objects. The ultimate objects of the contemplative part of the soul are eternal and imperishable beings which take place beyond all deliberation. Therefore, Aristotle calls them "the things that are highest by nature" (NE 1141b1-5) and claims that sophia, namely the ultimate knowledge of these highest entities, "must plainly be the most finished of the forms of knowledge" (NE 1141a15-20). By contrast, phronèsis 
is "concerned with things human" (NE 1141b5-10), that is, things subject to change.

Now, at the end of Nicomachean Ethics, Aristotle revisits this fundamental distinction between two spheres of being-and the corresponding distinction between two modes of thinking-from the vantage point of the human quest for happiness. The core of his argument can be recapitulated in the following way: if happiness is the activity of the soul in accordance with virtue, if this must be the virtue of the best part of the soul, and if the contemplative part, namely nous, is better than the deliberative one because of the ontological superiority of its objects, then, only the life of contemplation can promise perfect happiness. Aristotle supports this fundamental idea with a number of minor arguments by maintaining that contemplation is the "most continuous," the "pleasantest," and the "most self-sufficient" of all virtuous activities (NE 1177a20-30). Yet, in the final analysis, one can trace all these minor arguments back to the central claim that the priority of nous is based on the higher nature of its objects.

This claim, in turn, is built upon and find its justification in the metaphysical assumption that there is a correspondence between thought and being. As Aristotle puts it, it is "in virtue of a certain likeness and kinship with their objects" that the contemplative and the deliberative parts of the soul have their respective truths (NE 1139a10-15). Viewed in this light, nous is the best thing in us not only because the highest forms of being come within its range of grasp, but also and more importantly because it shares something in common with these highest forms of being and most notably with God, i.e., the thought thinking itself. Aristotle therefore does not hesitate to characterizes nous as something which is "divine," in the sense that its excellence goes beyond mere human existence. And it is only seen from the standpoint of this divinity that the contemplative life, the life of the nous, turns out to be better than the political life. As Aristotle himself remarks:

But such a life would be too high for man; for it is not in so far as he is man that he will live so, but in so far as something divine is present in him; and by so much as this is superior to our composite nature is its activity superior to that which is the exercise of the other kind of virtue. If reason [nous] is divine, then, in comparison with man, the life according to it is divine in comparison with human life. 
But we must not follow those who advise us, being men, to think of human things, and, being mortal, of mortal things, but must, so far as we can, make ourselves immortal, and strain every nerve to live in accordance with the best thing in us. (NE 1177b25-35)

The peculiarity of human existence is that, unlike other composite beings, namely other forms of life in the nature, it has the specific capacity to point beyond itself and share in the nature and happiness of God (Guthrie, 1981, p. 393). Yet, this does not mean that the excellence of nous is the ultimate aim of human life without which everything else would be vain and incomplete. On the contrary, human life has a purpose of its own which is not divine but strictly human. It is specifically for this reason that, right after the passage I have just quoted, Aristotle re-emphasizes the selfsufficiency of the political life: though "in a secondary degree" compared to divine happiness, he says, the life "in accordance with the other kind of virtue," namely the life in accordance with phronesis, "is also happy," because "the activities in accordance with this befit our human estate" (NE 1178a5-10). Hence, the point of the argument is that the political life is the good life for human beings qua human beings; yet, there is a better life which is divine in nature and to the extent that one has the capacity to go beyond one's human existence and share in the happiness of this better life, one must.

\section{Conclusion}

We are now in a position to see, I believe, how the superiority of the contemplative life and the self-sufficiency of the political life fit together in Aristotle's work. Despite the fact that these two strands of argument appear to stand in tension, they in fact have a common ground. Aristotle is led to acknowledge the superiority of the contemplative life by the same set of assumptions that enable him to plea for the self-sufficiency of the political life in the first place. These are assumptions about the ontological difference between the spheres of necessity and contingency, and the corresponding difference between theoretical and practical reason. Contemplative life is superior to political life insofar as it is structured around theoretical reason, which in turn addresses itself to those imperishable things that are highest by nature. But it is precisely for this reason that contemplation has nothing to tell us about the right thing to do vis-à-vis the contingency of concrete situations. The latter are the stuff that human affairs are made of, and to navigate ourselves among them with a view to happiness we 
need to draw exclusively on practical reason. Political life is self-sufficient in the sense that in its quest for happiness it does not need to be-and in fact cannot be-guided by the philosophical knowledge of the highest sort, but rather has to draw on its own resources, that is, on the counsels of practical reason.

Serdar Tekin, Ege Üniversitesi, Türkiye

\section{References}

Ackrill, J. L. (1974). Aristotle on eudaimonia. Proceedings of the British Academy, 60, 339-359. [Reprinted in Rorty, A. O. (Ed.). (1980). Essays on Aristotle's ethics (pp. 15-33). Berkeley: University of California Press.]

Aristotle (1925). Nicomachean ethics. (W. D. Ross, Ed. \& Trans.). Oxford: Clarendon Press.

Aristotle (1984). The politics. (C. Lord, Ed. \& Trans.). Chicago: The University of Chicago Press.

Beiner, R. (1983). Political judgment. Chicago: The University of Chicago Press.

Cooper, J. M. (1975). Reason and human good in Aristotle. Cambridge, Mass.: Harvard University Press.

Gadamer, H.-G. (1986). The idea of the good in Platonic-Aristotelian philosophy. (P. C. Smith, Trans.). New Haven: Yale University Press.

Gadamer, H.-G. (1999). Aristotle and the ethic of imperatives. (J. M. Knippenberg, Trans.). In R. C. Bartlett \& S. D. Collins (Eds.), Action and contemplation: studies in the moral and political thought of Aristotle (pp. 53-67). New York: SUNY Press.

Guthrie, W. K. C. (1981). A history of Greek philosophy, vol. 6: Aristotle. Cambridge: Cambridge University Press.

Kraut, R. (1989). Aristotle on the human good. Princeton: Princeton University Press.

Moline, J. (1983). Contemplation and the human good. Nous, 17, 37-53.

Nagel, T. (1972). Aristotle on eudaimonia. Phronesis, 17, 252-259. [Reprinted in

Rorty, A. O. (Ed.). (1980). Essays on Aristotle's ethics (pp. 7-14). Berkeley: University of California Press.]

Nussbaum, M. (1986). The fragility of goodness. Cambridge: Cambridge University Press.

O'Connor, D. K. (1999). The ambitions of Aristotle's audience and the activist ideal of happiness. In R. C. Bartlett \& S. D. Collins (Eds.), Action and contemplation: studies in the moral and political thought of Aristotle (pp. 107-129). New York: SUNY Press.

Rorty, A. O. (1980). The place of contemplation in Aristotle's Nicomachean ethics. In A. O. Rorty (Ed.), Essays on Aristotle's ethics (pp. 377-394). Berkeley: University of California Press. 